\title{
SANKSI PIDANA BAGI PELAKU PENIMBUN MASKER SELAMA MASA PANDEMI COVID-19
}

\author{
Kadek Wahyu Juniarta, Anak Agung Sagung Laksmi Dewi, Luh Putu Suryani \\ Fakultas Hukum, Universitas Warmadewa, Denpasar-Bali, Indonesia \\ wahjun21@gmail.com, laksmiidewi29@gmail.com, putusuryani099@gmail.com
}

\begin{abstract}
Abstrak
Penimbunan merupakan kegiatan mengumpulkan barang sehingga menjadi langka di pasaran dan dijual dengan harga yang mahal. Di masa pandemi covid-19 masker sangat dibutuhkan masyarakat, tetapi oknum yang tidak memiliki empati terhadap sesama masyarakat melakukan penimbunan terhadap masker sehingga menjadi langka dan harganya menjadi mahal. Tujuan penelitian ini untuk mengungkap pengaturan hukum terhadap pelaku penimbun masker di masa pandemi covid-19 serta sanksi pidana terhadap pelaku penimbun masker di masa pandemi covid-19. Dalam penelitian ini menggunakan pendekatan perundang-undangan dan pendekatan konseptual. Sumber bahan hukum yang diterapkan yaitu bahan hukum primer serta bahan hukum sekunder. teknik dalam pengumpulan bahan-bahan hukum yang digunakan adalah teknik studi kepustakaan yang kemudian dianalisis secara sistematis. Hasil penelitian menunjukkan bahwa sanksi pidana terhadap pelaku penimbun masker berdasarkan Pasal 107 Undang-Undang Nomor 7 Tahun 2014 dengan pidana penjara paling lama 5 tahun penjara atau pidana denda paling banyak Rp. 50.000.000.000,00. Dalam Undang-Undang Nomor 5 Tahun 1999 juga dapat dikenakan sanksi, berupa sanksi administratif, sanksi pidana pokok, sanksi pidana tambahan. Pemerintah harus dapat memberikan sanksi yang pantas untuk pelaku penimbun masker karena telah melanggar dan mengancam kepentingan masyarakat.
\end{abstract}

Kata Kunci: Penimbun Masker, Pidana, Sanksi

\begin{abstract}
Hoarding is an activity of collecting goods so that they become scarce in the market and are sold at high prices. During the COVID-19 pandemic, people really need masks, but people who don't have empathy for their fellow citizens hoard masks so that they become scarce and the price becomes expensive. The purpose of this study is to reveal the legal arrangements against the perpetrators of hoarding masks during the COVID-19 pandemic and criminal sanctions against those who hoard masks during the COVID-19 pandemic. In this study using a statutory approach and a conceptual approach. Sources of legal materials applied are primary legal materials and secondary legal materials. the technique in collecting legal materials used is a literature study technique which is then analyzed systematically. The results of the study indicate that criminal sanctions against perpetrators of hoarding masks are based on Article 107 of Law Number 7 of 2014 with a maximum imprisonment of 5 years or a maximum fine of Rp. 50,000,000,000.00. In Law Number 5 of 1999 sanctions can also be imposed, in the form of administrative sanctions, basic criminal sanctions, additional criminal sanctions. The government must be able to provide appropriate sanctions for the perpetrators of hoarding masks because they have violated and threatened the interests of the community.
\end{abstract}

Keywords: Hoarding Masks, Criminal, Sanctions

\section{PENDAHULUAN}

Sejak masa berlakunya Konstitusi Negara Indonesia telah menjamin kemakmuran masyarakat dengan melihat aspek perekonomian yang disusun atas asas kekeluargaan dengan menerapkan prinsip demokrasi. Pernyataan tersebut selaras dengan Pasal 33 UUD NRI 1945 tentang Perekonomian Nasional dan Kesejahteraan Sosial. Di dalam usaha dan perdagangan juga sering terjadinya persaingan antar pelaku usaha, persaingan terjadi apabila ada beberapa pelaku usaha bergerak dalam bidang usaha yang sama atau sejenis, bersama-sama menjalankan perseroan di tengah kawasan praktik (pemasaran yang sama), tiap-tiap perseroan berjuang semaksimal mungkin guna melampaui perseroan lainnya guna mendapatkan profit sebanyak-banyaknya (Utami \& S, 2017).

Salah satu persaingan usaha yang tidak sehat yang dilakukan oleh pelaku usaha adalah penimbunan barang pokok. Diamati pada maknanya penimbunan yaitu pekerjaan dimana menimbun 
suatu benda-benda mengakibatkan benda yang dimaksudkan dapat sulit ditemui dan menjadi kenaikan harga pada bursa lalu menjajakannya dengan nilai jual yang lumayan melambung tinggi mengakibatkan orang-orang atau penduduk sekitar susah untuk mencapainya. Pada Pasal 29 ayat (1) Undang-Undang Nomor 7 Tahun 2014 tentang Perdagangan menyatakan bahwa, "pelaku usaha dilarang menyimpan barang kebutuhan pokok atau barang penting dalam jumlah dan waktu tertentu dalam waktu berlangsungnya sukarnya barang tersebut ditemui dipasaran, kenaikan tarif yang melambung tinggi, serta halangan jalannya perniagaan suatu benda". Dalam garis besar UndangUndang tersebut mengisyaratkan bahwa setiap individu atau kelompok harus mementingkan prinsip kebersamaan, efisiensi berkeadilan untuk mewujudkan kesejahteraan dan keadilan bagi masyarakat Indonesia, tanpa menderogasi atau menimbun barang dalam keadaan genting (Aji \& Yunus, 2018).

Pada hakikatnya penimbunan terjadi karena beberapa faktor yaitu: faktor internal terjadi karena sifat khusus dari individu yang memiliki mental rendah. Sedangkan faktor eksternalnya, yaitu berpokok pangkal pada lingkungan luar dari diri manusia, terutama hal-hal yang mempunyai hubungan dengan timbulnya kriminalitas. Pada masa pandemi covid-19 masker sangat dibutuhkan masyarakat. Covid-19 adalah virus yang disebabkan oleh virus severe actue syndrome coronavirus-2 (SARS- CoV-2) menular dengan sangat cepat antar orang ke orang, virus ini mulai ditemukan di kota Wuhan, China pada akhir tahun 2019, hingga saat ini virus covid-19 atau disebut juga dengan virus corona telah menyebar hingga hampir seluruh negara di Dunia termasuk juga indonesia bahkan hingga saat ini obat dan vaksin untuk mencegah penyebaran virus covid-19 belum ditemukan.

Penyebaran yang sangat cepat dari manusia ke manusia lainnya menyebabkan jenis virus ini ditetapkan sebagai pandemi global. Akibatnya bukan hanya terhadap angka yang terinfeksi maupun kasus kematian yang terus meningkat, pandemi ini juga berimbas pada hampir semua aspek kehidupan seperti ekonomi hingga hukum. Di bidang ekonomi terpuruknya perekonomian di banyak negara di dunia mengakibatkan penyusutan perekonomian secara global. Negara Indonesia sendiri menarik kesimpulan untuk memutuskan kebijakan Pembatasan Sosial Berskala Besar (PSBB). Pemerintah Indonesia berpendapat peristiwa ini sebagai keadaan keperluan yang mengikat sesuai pemberitahuan World Health Organization (WHO), demi mengelola konsistensi moneter negara yang terpapar pandemi. penyusunan berikut terdapat pada Peraturan Pemerintah Pengganti UndangUndang Republik Indonesia Nomor 1 Tahun 2020 tentang Kebijakan Keuangan Negara dan Stabilitas Sistem Keuangan Untuk Penanganan Pandemi Coronavirus Disease 2019 (Covid-19) atau Dalam Rangka Menghadapi Ancaman Yang Membahayakan Perekonomian Nasional dan/atau Stabilitas Sistem Keuangan.

Virus tersebut menebar dalam waktu yang benar-benar gesit apabila bersentuhan frontal bersama pesakit oleh sebab itu tim kedokteran dalam menindaklanjuti penderita covid-19 tersebut pula paling membutuhkan media penjaga pribadi yang akseptabel semacam masker medis guna memenuhi kinerjanya dalam bertugas. akan tetapi keberadaan masker saat ini menjadi sangat langka dan harganya pun melonjak mahal dibanding harga normal sebelum adanya wabah virus covid-19. Setelah dilakukan pengusutan akan kelangkaan masker tersebut, ternyata terdapat banyak oknum yang tidak bertanggung jawab sedang memainkan perannya dalam pademi covid-19 ini. Melihat masker sangat dibutuhkan masyarakat disaat masa seperti ini dimanfaatkan oleh sekelompok oknum yang tidak memiliki rasa empati dan hanya mementingkan dirinya sendiri melakukan penimbunan masker sehingga membuat barang seperti masker mengalami kelangkaan sehingga mengakibatkan harga masker yang mahal.

Syarat perundang-undangan yang mengendalikan pembatasan pengumpulan ataupun kepemilikan benda yang dimaksudkan buat melindungi konsumen pasti sanggup digunakan dalam kaitannya dengan penumpukan masker. Syarat tentang penumpukan benda buat kepentingan konsumen ini dilihat pada:

1. Undang-undang Perdagangan (Undang-Undang Nomor 7 Tahun 2014) Peraturan Perundangundangan berhubungan berkenan perniagaan ini sendiri menandakan bahwasanya ditengah gerakan perniagaan, posisi negara sejatinya absolut supaya tersuguhnya suatu benda-benda masyarakat serta menghindari terjadinya kegagalan bursa.

2. Undang-undang Persaingan Usaha (Undang-undang Nomor 5 Tahun 1999) Undang-Undang Persaingan Usaha relevan digunakan manakala penimbunan termasuk ke dalam praktik monopoli dan persaingan usaha tidak sehat. 
Menurut (Triyana et al., 2021) Sanksi pidana tentang tindak pidana penimbunan dan pelipatgandaan harga masker dan hand sanitizer pada masa pandemic covid-19 terdapat pada Pasal 107 Undang-undang nomor 7 Tahun 2014 tentang Perdagangan. Lebih lanjut, (Kaharuddin, 2021) berpendapat bahwa pelaku penimbunan masker pada masa pandemi Covid-19 dapat dijerat sanksi pidana dengan Pasal tersebut. Hal ini perlu ditindaklanjuti sebab penimbunan masker dikala pandemi covid-19, dimanfaatkan oleh orang-orang yang melihat peluang dalam mendapatkan keuntungan yang pada akhirnya merugikan masyarakat pada umumnya serta Negara (Rizky, 2021).

Maka berdasarkan kajian terdahulu penelitian ini bertujuan untuk mengungkap pengaturan hukum terhadap pelaku penimbun masker di masa pandemi covid-19 serta sanksi pidana terhadap pelaku penimbun masker di masa pandemi covid-19.

\section{METODE PENELITIAN}

Tipe penelitian hukum yang digunakan pada penelitian ini adalah penelitian hukum normatif, yakni dilakukan dengan cara mengkaji berbagai peraturan yang bersifat formal seperti Undang-Undang dan literatur-literatur yang bersifat konsep teoritis yang kemudian dihubungkan dengan permasalahan yang menjadi pokok pembahasan (Marzuki, 2014). Dalam penelitian ini penulis menggunakan pendekatan perundang-undangan (The Statute Approach) dan regulasi yang bersangkut paut dengan isu hukum yang ditangani dan pendekatan konseptual (conceptual approach). Sumber bahan hukum yang diterapkan dalam observasi berikut terdapat 2 bahan hukum yaitu bahan hukum primer serta bahan hukum sekunder. teknik dalam pengumpulan bahan- bahan hukum yang digunakan adalah teknik studi keputusan yaitu dengan membaca, mencatat, mengutip, meringkas, dan mengulas informasi data-data dari peraturan perundang-undangan maupun literatur-literatur. Dengan mencari bahan dalam buku-buku terkait dengan sanksi pidana bagi pelaku penimbun masker di masa pandemi covid-19 yang dalam hal ini masuk ke dalam hukum persaingan usaha. Analisis bahan hukum dengan menggunakan metode pengolahan bahan hukum secara sistematis, yaitu dengan argumentasi hukum berdasarkan logika deduktif dan induktif.

\section{HASIL DAN PEMBAHASAN}

\section{Pengaturan Hukum Terhadap Pelaku Penimbun Masker di Masa Pandemi Covid-19}

Pada hakikatnya penimbunan terjadi karena beberapa faktor yaitu faktor internal dan eksternal, faktor internal terjadi karena sifat khusus dari seseorang yang memiliki mental rendah. Dan faktor eksternalnya yaitu berpokok pangkal pada lingkungan luar dari diri manusia, terutama hal yang mempunyai hubungan hubungan dengan kriminalitas. Penimbunan dalam penelitian ini adalah kegiatan yang melanggar hukum yang berupa penimbunan masker berarti tindakan yang dilakukan oleh pihak-pihak tertentu untuk mengumpulkan masker dalam jumlah besar kemudian dijual kembali dengan tujuan meraup keuntungan yang berlipat ganda. Dimana pada masa pandemi covid-19 ini masker sangat diperlukan oleh tenaga medis dan juga masyarakat. Kaidah digunakan guna membangun kesaksamaan pada tiap hak serta kewajiban yang dipunyai pada semua masyarakat. Disamping itu dengan hadirnya kaidah bisa pula memakai denda kepada siapa saja yang menentang kebijakan yang sudah dikerjakan dengan pihak berwenang. Permasalahan penimbunan masker oleh oknum pelaku usaha sehingga menjadi langka dipasaran dan dapat dijual dengan harga yang diluar kewajaran, menggambarkan bahwa pelanggaran tersebut tengah mengancam atau telah melanggar kepentingan masyarakat. Peranan negara melalui instrumen hukum pidana dalam konteks ini dapat menjadi pilihan terbaik guna menyelesaikan pelanggaran pelaku usaha tersebut yang sebenarnya telah melanggar ketentuan hukum.

Undang-Undang Nomor 7 Tahun 2014 Tentang Perdagangan dibentuk untuk mengedepankan nasional dan ditunjuk pada perlindungan pasar domestik maupun produk dalam negeri, membuat regulasi terhadap perdagangan dalam negeri serta memberikan perlindungan terhadap konsumen. Undang-Undang Nomor 7 Tahun 2014 Tentang Perdagangan Dimana mengatur seluruh aktivitas dan segala akibat hukum yang terkait dengan perdagangan, baik itu yang tertulis maupun tidak tertulis yang terjadi ditengah masyarakat agar berjalan dengan lancar, tertib, aman, dan tidak ada pihak yang dirugikan (Asikin, 2013).

Dalam ketentuan Peraturan Undang-Undang Nomor 5 Tahun 1999 Tentang Larangan Praktek Monopoli dan Persaingan Usaha Tidak Sehat, dimana Persaingan usaha merupakan hal yang paling menjadi perhatian dalam konteks dunia usaha. Suatu pelaksanaan monopoli dapat menjadikan suatu 
kasus di tengah dunia bisnis oleh sebab itu dapat menyulut persaingan bisnis yang tidak sehat serta keterkaitannya ialah belum bersaingnya bursa oleh sebab itu mengakibatkan penurunan kapabilitas saing pelaku bisnis.

Menurut ketentuan pasal 3 Undang-Undang Nomor 5 Tahun 1999 Tentang Larangan Praktek Monopoli dan Persaingan Usaha Tidak Sehat menegaskan pembentukan undang-undang ini bertujuan untuk :

a. Menjaga kepentingan umum dan meningkatkan efisiensi ekonomi nasional sebagai salah satu upaya untuk meningkatkan kesejahteraan rakyat

b. Mewujudkan iklim usaha yang kondusif melalui pengaturan persaingan usaha yang sehat sehingga menjamin adanya kepastian kesempatan berusaha yang sama bagi pelaku usaha besar, pelaku usaha menengah, dan pelaku usaha kecil

c. Mencegah praktik monopoli atau persaingan usaha tidak sehat yang ditimbulkan oleh pelaku usaha

d. Terciptanya efektivitas dan efisiensi dalam kegiatan usaha

Dilihat dengan bersama-sama maksud di atas, bisa dijelaskan bahwasannya oleh sebabnya dasar maksud dari Peraturan Perundang-Undang Persaingan Usaha ialah guna mewujudkan daya guna ditengah perniagaan bisnis demi pengembangan kesejahteraan khalayak banyak. Undang-Undang Nomor 5 Tahun 1999 Tentang Larangan Praktek Monopoli dan Persaingan Usaha Tidak Sehat menghendaki agar kegiatan usaha berlangsung secara sehat, sehingga praktik-praktik monopoli dan berbagai kecurangan dalam berusaha harus dicegah supaya tidak mengganggu kepentingan umum.

Dalam konteks penelitian ini tidak semua perjanjian dan kegiatan yang dilarang itu relevan, maka bagian berikut hanya membahas larangan perjanjian dan kegiatan yang memiliki relevansi. Berikut larangan perjanjian dan kegiatan yang relevan untuk penelitian ini:

a. Oligopoli

Oligopoli adalah keadaan pasar dengan produsen pembekal barang hanya berjumlah sedikit sehingga mereka atau seseorang dari mereka dapat mempengaruhi harga pasar. Pantangan oligopoli membidik dalam pasal 4 ayat (1) Undang-Undang Nomor 5 Tahun 1999 mengenai Larangan Praktek Monopoli dan Persaingan Usaha Tidak Sehat yang berbunyi "pelaku usaha dilarang membuat perjanjian dengan pelaku usaha lain untuk secara bersama-sama melakukan penguasaan produksi dan pemasaran barang dan jasa yang dapat mengakibatkan terjadinya praktek monopoli dan persaingan usaha tidak sehat".

b. Perjanjian Penetapan Harga

Penetapan harga adalah suatu wujud pengingkaran kepada kaidah persaingan usaha dikarenakan pola negosiasi tarif hendak secara serentak membebaskan kompetisi dimana sejatinya dilakukan diantara industri-industri di bursa. Larangan ini mengacu pada Pasal 5 ayat (1) Undang-Undang Nomor 5 Tahun 1999 tentang Larangan Praktek Monopoli dan Persaingan Usaha Tidak Sehat yang berbunyi "Pelaku usaha dilarang membuat perjanjian dengan pelaku usaha pesaingnya untuk menetapkan harga atas suatu barang atau jasa yang harus dibayar oleh konsumen atau pelanggan pada pasar bersangkutan yang sama".

c. Kartel

Kartel ialah persekutuan atau persekutuan antara suatu kelompok produsen barang serupa dimana bertujuan guna mengawasi pembuatan, tarif, serta pemasarannya. Pantangan kartel berikut membidik dalam Pasal 11 Undang-Undang Nomor 5 Tahun 1999 mengenai Larangan Praktek Monopoli dan Persaingan Usaha Tidak sehat yang berbunyi "Pelaku usaha dilarang membuat perjanjian dengan pelaku usaha pesaingnya, yang bermaksud untuk mempengaruhi harga dengan mengatur produksi dan atau pemasaran suatu barang dan atau jasa, yang dapat mengakibatkan terjadinya praktek monopoli dan persaingan usaha tidak sehat".

d. Monopoli

Suatu pelaku usaha atau suatu kelompok usaha dapat dikatakan patut diduga melakukan monopoli ini jika, antara lain, menguasai lebih dari 50 persen pangsa pasar satu jenis barang atau jasa tertentu. Larangan ini merujuk pada Pasal 17 ayat (1) Undang-Undang Nomor 5 Tahun 1999 tentang Larangan Praktek Monopoli dan Persaingan Usaha Tidak Sehat yang berbunyi "pelaku usaha dilarang melakukan penguasaan atas pembelian ataupun penjualan benda ataupun pelayanan dimana mampu membuat kegiatan monopoli maupun persaingan bisnis tidak sehat".

e. Penguasaan Pasar 
Larangan ini didasarkan pada Pasal 19 Undang-Undang Nomor 5 Tahun 1999 tentang Larangan Praktek Monopoli dan Persaingan Usaha Tidak Sehat, yang melarang pelaku usaha baik sendiri maupun bersama pelaksana bisnis yang lain dapat melaksanakan beberapa aktivitas yang bisa membuat berlangsungnya kegiatan monopoli atau persaingan bisnis yang tidak sehat salah satunya, menghalangi perkembangan serta pemasaran benda ataupun pelayanan kepada bursa yang berkaitan.

\section{Sanksi Pidana Terhadap Pelaku Penimbun Masker}

Kitab Undang-Undang Hukum Pidana (KUHP) yang menjadi sumber hukum pidana di Indonesia telah mengatur bentuk hukuman pidana dalam pasal $10 \mathrm{KUHP}$, yaitu :

1. Pidana Pokok, terbagi atas :

a. Pidana mati adalah hukuman paling berat dari semua pidana yang diakui di dalam hukum positif Indonesia. Tercantum dalam ketentuan Peraturan Perundang- undangan Pasal 69 ayat (1) KUHP, Dengan demikian pidana mati merupakan pidana terberat dibandingkan dengan jenis-jenis pidana lainnya.

b. Pidana penjara adalah suatu wujud kriminalitas dimana berwujud penyekatan keleluasaan beraktivitas dimana dijalankan guna mengunci serta memasukkan narapidana ke tengah suatu lembaga pemasyarakatan (LP) guna mengharuskannya untuk mematuhi keseluruhan kaidah tata tertib yang berlaku di dalam lembaga pemasyarakatan tersebut (Elwi Danil dan Nelwitis, 2002:47).

c. Pidana kurungan tercantum dalam Ketentuan Peraturan Perundang-undangan Pasal 18 ayat (1) KUHP pidana kurungan diberlakukan untuk individu yang membuat suatu delik kriminal, ataupun sebagai alternatif pidana denda dimana belum boleh diuangkan.

d. Pidana denda ialah suatu wujud ganjaran untuk individu yang mengharuskannya untuk membayar kesalahan atas perbuatan yang telah dibuatnya dengan sejumlah uang tertentu. Pidana Denda Tercantum dalam Ketentuan Peraturan Perundang- undangan Pasal 30 ayat (2) KUHP

e. Pidana tutupan, pada Pasal 10 KUHP dicantumkan pidana tertutup sebagai pidana pokok bagian terakhir di bawah pidana denda.

2. Pidana Tambahan, yang terbagi atas :

a. Pencabutan hak-hak tertentu

Hakim melalui putusannya dapat mencabut hak-hak tertentu dari seorang terpidana. Yang dimaksud hak-hak tertentu diatur dalam Pasal 35 ayat (1) KUHP.

b. Perampasan barang-barang tertentu

Pidana perampasan barang-barang tertentu merupakan jenis pidana terhadap harta kekayaan, sama halnya seperti pidana denda. Ketentuan mengenai perampasan barangbarang tertentu Tercantum dalam ketentuan Peraturan Perundang-undangan pasal 39 KUHP.

c. Pengumuman putusan hakim

Pengumuman putusan hakim tercantum dalam Ketentuan Peraturan Perundang- undangan Pasal 43 KUHP.

Sebagaimana telah diketahui bahwa penimbunan masker adalah kegiatan yang melanggar hukum yang diatur dalam Pasal 29 ayat (1) Undang-Undang Nomor 7 Tahun 2014 tentang Perdagangan Oleh karena masker merupakan barang yang sangat dibutuhkan pada masa pandemi covid-19 untuk menjaga kesehatan bahkan keselamatan masyarakat terutama tenaga medis, maka sudah seharusnya ada perubahan terkait klasifikasi barang penting. Dalam kaitannya dengan penegakan hukum untuk menindak pelaku penimbunan masker, hal itu mendorong dilakukannya penemuan hukum (rechtsvinding) maupun penafsiran oleh aparat penegak hukum. Kondisi demikian yang menjadi dasar bagi aparat penegak hukum untuk menggunakan pertimbangan hukum dengan menggunakan penafsiran sistematis sebagai jalan tengahnya. Penafsiran sistematis yaitu suatu interpretasi untuk menentukan arti atau makna norma/kaidah hukum suatu pasal undang-undang harus dikaitkan dengan ketentuan pasal lainya dalam kerangka satu sistem hukum (Atmaja \& Budiartha, 2019). Dari aspek hukum pidana, kelima larangan dalam Undang-Undang Nomor 5 Tahun 1999 Tentang Larangan Praktek Monopoli dan Persaingan Usaha Tidak Sehat tersebut juga termasuk sebagai larangan yang dapat dikenakan sanksi. Undang- Undang Nomor 5 Tahun 1999 menetapkan 2 
macam sanksi yaitu sanksi administratif dan sanksi pidana yang terdiri dari pidana pokok dan pidana tambahan (Mahendrawati \& Sudarsono, 2018).

1. Sanksi administrative

Sanksi administratif merupakan satu tindakan yang dapat diambil oleh Komisi terhadap pelaku usaha yang melanggar Ketentuan Peraturan Perundang-undangan Pasal 47 UndangUndang Nomor 5 Tahun 1999

2. Sanksi pidana

a. Sanksi pidana pokok

Pasal 48 Undang-Undang Nomor 5 Tahun 1999 menentukan bahwa sanksi pidana pokok meliputi pidana denda minimal Rp. 25.000.000.000,00 dan maksimal Rp. 100.000.000.000,00.

b. Pidana tambahan

Pidana Tambahan sendiri terdapat dalam ketentuan Peraturan Perundangn- undangan Pada Pasal 49 Undang-Undang Nomor 5 Tahun 1999. Instrumen hukum pidana dalam UndangUndang Nomor 5 Tahun 1999 tentang Larangan Praktek Monopoli dan Persaingan Usaha Tidak Sehat ini urgen dan relevan digunakan untuk menindak pelaku penimbunan masker pada saat covid-19. Perilaku penimbunan masker tidak hanya berkaitan dengan hak masyarakat yang telah dilanggar, namun juga negara yang tengah genting akan kebutuhan masker pada saat covid-19. Bagi negara penimbunan masker yang berdampak pada kelangkaan barang dan harga yang mahal ini tentu menghambat tugas dan tanggung jawab negara dalam memenuhi hak asasi manusia dan hak konstitusional warganya mendapatkan hak atas kesehatan.

Ketentuan pidana dalam Undang-Undang Nomor 5 Tahun 1999 sebagaimana telah dibahas hanya mengakomodasi sanksi pidana pokok berupa denda atau kurungan sebagai gantinya. Kendati terdapat kelemahan tersebut, upaya lain dari aspek hukum pidana sebenarnya dapat ditempuh untuk menindak penimbunan masker, yaitu melalui penerapan ketentuan pidana tambahan selain pidana pokok. Pada prinsipnya, penerapan pidana tambahan bersifat alternatif. Ia bukan sanksi yang wajib dijatuhkan, atau hanya merupakan opsi jika pidana pokok dianggap kurang. Dengan demikian, pidana pokok maupun pidana tambahan sesungguhnya dapat sama-sama diberlakukan secara proporsional dan efektif. Karena itu, motif ekonomi dan situasi pandemi covid-19 yang sedang berlangsung, sesungguhnya menjadi alasan kuat bagi pemberlakuan pidana pokok dan tambahan secara sekaligus dalam penindakan penimbunan masker yang memang dapat membahayakan kesehatan dan bahkan keselamatan masyarakat.

\section{SIMPULAN DAN SARAN}

\section{Simpulan}

Pengaturan hukum terhadap pelaku penimbun masker di masa pandemic Covid-19 diatur dalam Pasal 29 ayat (1) Undang-Undang Nomor 7 Tahun 2014 Tentang Perdagangan. Penimbunan masker merupakan kejahatan yang bermotif ekonomi yang melanggar hukum, pelanggaran tersebut tengah mengancam atau telah melanggar kepentingan masyarakat. Adapun sanksi pidana terhadap pelaku penimbun masker di masa pandemi covid-19, sebagaimana telah diketahui penimbunan masker di masa pandemi covid-19 merupakan kegiatan yang yang melanggar ketentuan Pasal 29 ayat (1) Undang- Undang Nomor 7 Tahun 2014 Tentang Perdagangan.

\section{Saran}

Diharapkan bagi pemerintah untuk memantau produksi masker dan membatasi pembelian masker dalam jumlah yang banyak untuk mencegah terjadinya penimbunan terhadap masker agar masyarakat kecil juga dapat membeli dengan harga yang sewajarnya. Diharapkan agar pemerintah dan penegak hukum dapat memberikan sanksi yang pantas didapatkan untuk pelaku penimbun masker di masa pandemi covid-19. Agar memberikan efek jera terhadap pelaku penimbun masker karena sangat merugikan negara dan masyarakat. 


\section{DAFTAR PUSTAKA}

Aji, A. M., \& Yunus, N. R. (2018). Basic Theory of The Law and Justice. Jurisprudence Institute, Jakarta.

Asikin, Z. (2013). Hukum Dagang. Rajawali Pers, Jakarta.

Atmaja, I. D. G., \& Budiartha, I. N. P. (2019). Sistematika Filsafat Hukum. Setara Press, Malang.

Kaharuddin, K. A. (2021). Pertanggungjawaban Pidana Bagi Pelaku Penimbunan Masker Pada Masa Pandemi Covid-19 (Studi Di Polres Kota Madiun). Jurnal Revolusi Indonesia, 1(9), 954-970.

Mahendrawati, N. L. M., \& Sudarsono. (2018). Larangan Monopoli dan Persaingan Usaha Tidak Sehat dalam Usaha Perdagangan di Indonesia. Surya Pena Gemilang, Malang.

Marzuki, P. M. (2014). Penelitian Hukum. Prenada Media Group, Jakarta.

Rizky, M. A. (2021). Penegakan Hukum terhadap Praktek Tindak Pidana Penimbunan Masker Ilegal di Tengah Pandemi Covid-19 Dihubungkan dengan Undang-Undang Nomor 7 Tahun 2014 dentang Perdagangan. Prosidiing Ilmu Hukum, 7(1), 119-123.

Triyana, I. G. A., Sugiartha, 1 N. G., \& Karma, N. M. S. (2021). Sanksi Pidana Terhadap Penimbunan Masker Medis dan Hand Sanitizer Pada Masa Pandemi Covid-19. Jurnal Interpretasi Hukum, 2(2), 291-296.

Utami, W., \& S, Y. A. (2017). Pengantar Hukum Bisnis Dalam Perspektif Teori dan Praktiknya di Indonesia. Jala Permata Aksara, Jakarta. 